\title{
The Application of International Trade Theories to Agriculture
}

\author{
Nahanga Verter \\ Faculty of Regional Development and International Studies, Mendel University in Brno \\ Email: xverter@mendelu.cz
}

\section{Doi:10.5901/mjss.2015.v6n6s4p209}

\begin{abstract}
International trade in agriculture has recently been recognized as an important driver of economic growth, especially in SubSaharan Africa (SSA) where agriculture is the major export products. This paper surveys a broad range of both traditional and modern theories of trade with reference to agriculture. Historically, trade in agrarian products was concentrated on comparative and factor endowment models. The application of modern theories in agriculture has been increasing in recent years. In this survey, it could be concluded that those models help in explaining the current patterns or the factor content of trade. All the theories appear to be less relevant in SSA countries than in industrialized countries. For instance, even though agriculture is the primary employer of labour, principal export commodities from the SSA countries, they are not the top major exporters of agricultural products. Instead, some of them are net importers of food and agricultural products. This is partly, due to limited market access of the raw products, low productivity due to limited capital and technology. In order to gain more from trade and experience a favourable trade balance in agriculture, SSA countries should take advantage of their unique climatic conditions and concentrate on producing and processing those commodities that cannot be produced by the West in large quantities for economies of scale, self-sufficient and exports.
\end{abstract}

Keywords: agricultural products, comparative advantage, economies of scale, export and import, SSA.

\section{Introduction}

The World Trade Organization (WTO) has made tremendous progress in the expansion of global trade through the reduction of trade barriers such as quotas, subsidies and import tariffs (Verter and Osakwe, 2015). Notwithstanding, trade restrictions persists in raw agricultural commodities (Verter and Bečvářová, 2014). Trade barriers in primary products have hampered the expected mutual gains from trade as advocated by international trade theories.

Economists have some arguments in support of trade in agricultural commodities: trade brings varieties of food that increase choices for the population; trade maintains stable demand and supply for food that allows efficient exchanges (Stiglitz and Charlton, 2007; Erokhin and Ivolga, 2013). The agricultural trade could stimulate growth, especially in developing countries that agriculture forms a substantial share of their export products and foreign earnings. Globally, the study of international trade in agriculture and food has tremendously increased in recent decades (Josling et al., 2010). The landscape of trade in agriculture has been changing across the globe. However, more attention is given to the trade in processed food and agricultural products than trade in raw agricultural products (Berkum and Meij, 2000) which form the bulk of poor countries' markets.

Some studies have attempted to link trade theories to food and agriculture in recent times (Abbott and Kallio, 1996; Berkum and Meij, 2000; Josling et al., 2010; Pokrivčák, Ciaian and Kancs, 2011; Campi and Duenas, 2014), however, most of these studies concentrated mainly in processed food and agricultural products in the developed countries or regional trading blocs such as the United States of America (USA) and the European Union (EU). To the best of my knowledge, these studies have not given much attention to trade theories with reference to trade in raw agricultural products of Sub-Saharan Africa (SSA), thus the importance of this study.

\section{Materials and Methods}

The aims of this article are, firstly, to survey both traditional and modern theories of international trade. Secondly, to link those theories with trade in food and agricultural commodities. More attention is paid to agricultural trade in advanced economies and SSA countries, which food and agriculture account for a substantial share of their merchandise trade.

This study mainly used secondary data such as annual statistical data, books and journal articles for the analysis. Annual statistical data for descriptive analysis are obtained from the annual statistical reports of United Nations 
Conference on Trade and Development, Food and Agriculture Organization of the United Nations, and the World Bank World Development Indicators. The descriptive statistic is chosen to describe the historical data of food and agricultural trade, and the trade patterns in the developed countries and the SSA countries, with reference to both traditional and modern trade theories.

\section{Traditional Trade Theories}

\subsection{Mercantilism}

Historically, mercantilist is regarded as the first theories of international trade. The theory was dominated by cross-border trade discussions and policies in the West between $16^{\text {th }}$ and $18^{\text {th }}$ centuries. The model stressed that nations should simultaneously discourage imports through tariffs and quotas and encourages exports through export subsidies and support, in addition to the collection of precious metals. Mercantilism promoters promoted export trade because its increase a country's good (wealth) and vice versa to import (Paul, 2008). The theory argued that for a country to maintain a favourable balance of trade, import substitution and the accumulation of financial wealth (mostly gold and silver) should be encouraged, and export should be promoted. According to a notable promoter of mercantilism, Thomas Mun, "the ordinary means, therefore, to increase our wealth and treasure is by foreign trade, wherein we must ever observe this rule; to sell more to strangers yearly than we consume of theirs in value" (Mun, 1664, P. 7). The theory assumed that the world has a fixed and limited amount of wealth; therefore, for a nation to improve its wealth, it has to either directly or indirectly take some resources from another country.

Critics of the mercantilist model argued that the theory is 'a false unity to disparate events', which to some extent, hindered growth, especially from the developing nations. For instance, David Hume's price-specie-flow doctrine (18th century) argued that a favourable balance of trade would be possible, albeit only in the short run. Smith (1776) stressed that the mercantilist system was nothing but a tremendous conspiracy by the industrialists and merchants to the detriment of consumers. He argued that the theory not give domestic consumers the opportunity to choose varieties of products that were produced in other countries. The theory was regarded as a 'zero-sum game', or a 'win-lose game' which means that any gain made by a nation might bring a corresponding loss to the other country that involved in the trade. Ekelund and Tollison (1981) viewed 'Mercantilism as a rent-seeking society'.

\subsection{Absolute Advantage Trade Theory}

This theory was coined by Adam Smith (1776) who is regarded as the father of modern economics, and who was the first person that advocated free trade. He defines absolute advantage as the process by which an individual or country can produce a particular product at a lower cost than another or in the other country. Therefore, a country that trade across national borders should specialize in producing goods that it has an absolute advantage over another.

Smith argued "what is prudence in the conduct of every private family can scarce be folly in that of a great kingdom. If a foreign country can supply us with a commodity cheaper than we ourselves can make it, better buy from them with some part of the produce of our own industry employed in a way in which we have some advantage" (Smith, 1776, p. 357). Smith maintained that the specialization in the production of goods and services would lead to increasing the total output. In addition, global efficiency in the utilization of available resources when a country exports a portion of goods it produces at a lower cost and imports the products that its trading partner produces at a lower cost than at home. Smith argued that as advocated by mercantilism, it was impossible for countries involved in a trade to have benefited from such transactions because the export of one country is another country's import.

According to Smith, all countries would benefit if they practice the free trade and specialize in what they could produce cheaply. This implies that trade is possible when a country produces a particular commodity using less labour about the other state and vice versa. Smith argued that, in the era of the free market, even though a state's employment might exceed the domestic consumption, it would encourage the nation to improve its productive powers. Consequently, the revenue and wealth of the country would be tremendously accelerated.

Smith assumed that every country or person had an absolute advantage over another. What if the nation has an absolute advantage in producing everything? Will the country continue to produce all the products for domestic consumption and exports? Will it be possible for both countries to trade and have mutual benefits when one country produces all the goods? Comparative advantage theory has answered these questions. 


\subsection{Comparative Advantage Theory}

To address some issues that were not answered in the absolute advantage theory, the theory of comparative advantage was propounded by David Ricardo (1817). Ricardo argued that countries would mutually benefit from trade even if one has an absolute advantage over the other in producing of all the goods that they trade. Ricardo stressed that the country should specialize in producing goods that it has the highest output at the lower opportunity cost relative in comparison with the other country. Arguably, so long as the costs of production differs between countries that trade, each nation has a comparative advantage for a product that recorded highest in production efficiency.

Comparative advantage theory is based on some of the following assumptions: only two countries involve in trade; trade only two products; there is perfect competition; no effects of trade on income distributions between countries that trade together; the level of technology differences exist across countries; trade is necessary partly due to the differ in labour productivity in countries; labour is the only factor of production; no trade restrictions and there is a balance of trade and no costs of transportation between countries. However, critics stressed that the theory failed to explain the reasons why labour productivity and technologies differ between countries that involved in the trade. The Factor proportions theory based on comparative advantage model attempted to throw light on why labour productivity and technology vary in countries.

\subsection{Heckscher-Ohlin Trade Theory}

The Heckscher - Ohlin Theorem (H-O model) was coined by Eli Heckscher (1919), and Bertil Ohlin (1933) was based on the Ricardian comparative advantage. The model is also called 'factor endowment theory' because it stressed that the pattern of production and trade across national borders depended on the domestic factor endowments. Foreign trade takes place due to the differences in the comparative costs of factors of production that arises, due to the abundant or insufficient resources (labour and capital) within countries. Therefore, countries should produce and export products that they have a cheap factor(s) of production and import goods or inputs that are scarce locally (Blaug, 1992). A difference in the use of capital per worker was identified as a significant factor in explaining differences in labour productivity in countries (Berkun and Meijl, 2000). H-O maintained that Factor endowments are immobile between nations, and countries use various combinations to produce different products. The outputs are suggested to have constant returns to scale and identical factors and production functions in nations involved in the trade.

In contrast to the Ricardian model which assumes that only one factor of production (labour) existed, $\mathrm{H}-\mathrm{O}$ model assumes that two factors of production (labour and capital) producing two commodities could be freely moved between two identical countries. This model is also known as the ' $2 \times 2 \times 2$ model' which simply means 2 countries involve in trade, producing 2 products, and have 2 homogeneous factors of production. The model further stressed that, unlike the Ricardian's comparative advantage, internally; an economy guarantees the effects of income distribution through trade.

Due to the tedious task of determining the pattern of trade in the world of many products, instead of the $\mathrm{H}-\mathrm{O}$ model, the Heckscher-Ohlin-Vanek (HOV) theory, on the other hand, predicts the factor content side of international trade. They argue that produced goods and services are the products of labour, capital or land factors of production. The HOV model maintains that nations would export goods and services of, their abundant production factors (Vanek, 1968). This suggests that in the capital-abundant nations, the capital-labour ratio is likely to be higher in production in comparison with consumption (Leamer, 1980). By and large, $\mathrm{H}-\mathrm{O}$ model concluded that capital-abundant nation would export capitalintensive goods, and in return, import labour-intensive goods. Similarly, labour- the abundant country would export labour-intensive commodities, and in return, import capital-intensive goods.

However, results from some empirical tests contradict H-O's hypothesis (see Leontief paradox, 1953; country similarity theory by Linder, 1961; and Bowen, Leaner and Sveikauskus, 1987). Wassily Leontief and others developed the input-output model in the 20th century. Leontief (1953) was the first person that empirically tested $\mathrm{H}-\mathrm{O}$ model, which stated that each country exports the products that use its abundant production factors intensively. Contrary to the $\mathrm{H}-\mathrm{O}$ model, Leontief result shows a paradoxical conclusion that the United States of America-the world's most capitalabundant country - exported labour-intensive products and imported capital- intensive products. In the same fashion, Trefler (1993) empirically tested the theory and confirmed that Leontief was right, after all. Studies by Trefler further revealed that the absolute levels of technology vary between developed and less developed countries. On the other hand, Bowen, Leaner and Sveikauskus (1987) investigate H-O model for twelve inputs in 27 nations. Using the USA methodology matrix, they find no relationship between factor content and net exports in the countries under study.

The negative or contradictory results of the factor proportions model have left global economists searching for alternative explanations of trade patterns (Goldin, 1990). After the 1950s, studies have revitalised the factor content 
model of trade because the levels of technology to vary in nations. Nevertheless, the same difficulty remains with the Ricardian model; the cogent reasons why the levels of technology differ in countries had not been vividly explained by the traditional theories of trade. More so, in recent decades, substantial volumes of exports and imports have taken place in countries with similar factor endowments and technology. Given the unexplained patterns of trade, the needs for the modern theories of international trade are inevitable.

\section{Modern International Trade Theories}

\subsection{Country Similarity Theory}

This theory was postulated by a Swedish Economist, Staffan Burenstam Linder in 1961, to describe the patterns global trade. Linder run an empirical analysis after Leontief hypothesis. His results suggest that rather than differences in the supply side of production factors as assumed by $\mathrm{H}-\mathrm{O}$ factor- proportions, products are mostly traded based on similar demand structures in countries. Linder argued that countries with similar demands for goods might well establish related industries. Hence, they will trade with each other, but differentiated products.

Linder assumes that consumers living in countries that have similar levels of per capita income and development may well have the same tastes and could proportionally consume the same quality products. Therefore, those countries are likely to trade and consume the same quantity and quality of goods and services. Using Linder's approaches, most econometric studies have found a positive association between the share of intra-industry trade and the average level of per capita income in countries (Bergstrand, 1990).

\subsection{International Product Life Cycle Theory}

The model was propounded by Raymond Vernon (1966) in response to the failure of the H-O's trade model. In explaining the pattern of international trade, Vernon proposed five stages of product life cycle. Firstly, the introduction of new production to the market stimulates trade, mostly takes place in similar regions or countries. Secondly, the growth stage leads to competition, capital intensity and increase for exports and transfer of technology from the innovating country, and foreign investment to other countries. Thirdly, maturity leads to the decline in exports from the innovating country. Fourthly, the saturation takes place at a stage in which the sales or distribution of product(s) reach the peak position, and finally, the phase of declining as overseas production intensified. It is characterized by a concentration of production in the developing countries, thus innovating country becoming a net importer of some products that they formerly introduced to the market. Vernon stressed that early in the life-cycle of a product, the labour used is connected with that properties come from the producing nations. Production of this product is moved to other countries after they are known and utilized in a domestic market.

To sum up, Vernon's theory stressed that companies would first and foremost, produced and locally consumed a product before it goes to other countries. In the long run, the production and sales locations of the enterprise's products may change. A comparative advantage of a given product may shift from one country to another.

\subsection{Intra-Industry Trade}

Intra-industry trade (IIT) is in sharp contrast with the traditional trade theory, which based on constant returns to scale and perfect competition. The IIT model stressed that international trade takes place as a result of economies of scale, product differentiation and imperfect competition between and within industries and countries. The first far-reaching study of the extent of IIT was carried out by Grubel and Lloyd (1971). They devised an index called the Grubel-Lloyd index to measure the degree of this type of trade as a share of total trade as follow:

$$
\mathrm{GL}_{i}=\frac{\left(X_{i}+M_{i}\right)-\left|X_{i}-M_{i}\right|}{X_{i}+M_{i}}=1-\frac{\left|X_{i}-M_{i}\right|}{X_{i}+M_{i}} \quad \therefore 0 \leq G L_{i} \leq 1
$$

Where;

$X_{i}$ is the export; $M_{i}$ denotes the import of good $i$. Therefore, If $G L_{i}=1$, there is only intra-industry trade, no interindustry trade. This means, for example; a nation understudy exports the same quantity of products $i$ as much at it imports. In the opposite direction, if $G L_{i}=0$, there is no intra-industry trade, only inter-industry trade. This would mean that the nation understudy only either exports or only imports product $i$. Grubel and Llyoyd (1971) confirmed high ratios in the main advanced economies.

Before IIT model was adequately developed, Loertscher and Wolter (1980) had already established some stylized 
facts about partial correlations between the nation and industry features as well as the extent of trade overlap. Their result shows that the share of intra-industry trade is high when the trading partners are well developed and do not vary much in their level of growth and development. Also, when they are large, they do not differ too much in size (Helpman, 1999).

In the same direction, studies by Krugman (1980); Helpman and Krugman (1986) and Helpman (1999) indicate that product differentiation, economies of scale, and various kinds of behaviour are consistent with factor price equalization. Similarly, IIT with homogeneous products mostly takes place within industrialized countries. Bergstrand (1990) finding suggests a greater similarity of two nations' per capita incomes might associate with more IIT both for supply by Heckscher-Ohlin-Samuelson (H-O-S) and demand by Chamberlin-Linder reasons simultaneously. In the same fashion, McCorriston and Sheldon (1991) confirm that IIT exist between the EU and the USA in food and agricultural commodities. Notwithstanding, Bergstrand (1990) stresses that those propositions evolved from a restricted set of assumptions. IIT in this model develops only among horizontally differentiated products; other models have shown such trade among homogenous goods under different market structures. H-O-S models have predicted two-way trade in vertically differentiated products.

Davis (1985) argues that the theoretical issue addressed on might also have significant implications for trade policy. The empirical importance of IIT, and 'the perceived inability of the traditional theories to account for it, have been taken as key pieces of evidence in favour of the increasing returns theory. Increasing returns, of course, are often associated with imperfect competition. Yet, IIT 'could arise, per the traditional theories, even if returns to scale are constant and markets perfectly competitive. A determination of the cause of this trade would then have significant implications for appropriate trade policy, which depends critically on the underlying market structure' (p. 203).

\subsection{The New Trade Theory}

The new trade theory (NTT) was championed by Paul Krugman (1979) and others (Helpman and Krugman, 1986). They pointed out that comparative advantage or factor endowment models are necessary. Nevertheless, the theories did not adequately explain patterns of cross-border trade. Krugman emphasized that the increasing returns to scale and network effects that take place in key firms were seemingly the drivers of trade patterns. Krugman calls these companies as the market first movers, and they get first mover advantages, mostly based on cost advantage. Krugman argues that if there are enormous economies of scale, and increasing returns to specialization in an industry, global demand for goods and services may support only one or fewer number of firms.

Consequently, in the long run, for firms to be able to enter a market and remains competitive in a given country, they may require subsidies and other support from the government. The Krugman model has, among others, assumes two identical countries (home $(H)$ and foreign $(F)$ ) in terms of technology and preferences. There is one non-traded factor of production (labour) and equal endowment across nations, $L_{H}=L_{F}$. There are a significant number of competitors in the market, with many varieties of products (i.e. product differentiation). Each firm produces its variety of goods and acts as a monopolist. Arguably, nations that had an early entrant to such businesses have a first-mover advantage. In the long run, the price may fall as more firms enter the market; consumer preferences are homothetic and identical across countries. Krugman (1981) opines that intra-industry takes place when there is an exchange of varieties of the same differentiated goods.

Krugman (1979 and 1980) argues that the gains from trade arise due to a larger number of varieties of goods available to consumers. Greater production of each type results in higher real income as prices are reduced due to increasing market size and competition. Krugman maintains that comparative advantage does not solely depend on the differences in factor endowments; rather it depends on the economies of scale and network effects that occur in the critical industries.

\subsection{Porter's National Competitive Advantage Theory}

This model popularly known as Porter's Diamond was coined by Michael Porter (1990). Trade patterns are determined by the level of businesses and economic situations in countries that traded. Porter pointed out that, 'the only meaningful definition of competitiveness at the national level is national productivity' (Porter, 1990, pp. 6). Porter postulated four keys to a state's competitive advantage in comparison to the other nations: factor conditions; demand conditions; related and supporting industries; and firm strategy, structure and rivalry.

According to Porter (1990), factor conditions are the basic (i.e. natural resources, location, vegetation and climatic condition and fertile land for agricultural production) and the advanced (i.e. communication, skilled workers, deregulation 
of markets, research and development) determinants available in a given economy. Demand conditions are the level of customers' demand for goods and services produced in a particular economy. Related and supporting industries are determined by the level of investments in advanced factors of production and the spill over from the similar industries that lead to both the domestic and global competitiveness of industries. For firm strategy, structure and rivalry, Porter argues that they are the conditions in a country that explain how companies are established, managed, organized, controlled, and that determines the features of domestic competitions. Porter maintained that local rivals and the search for competitive advantage within a country could stimulate organizations or companies with bases for attaining such competitive advantage on a more international stage.

Porter further maintained that nations should export products from those companies in where all the four pillars of the diamond are conducive, whereas, in that area that are not favourable, countries should import. The Government has a vital role to play in ensuring that businesses maintain a high quality of production, service delivery and healthy competition among firms (Grant, 1991). Nations are likely to benefit from trade even if they do not vary in factor endowments.

\subsection{The Gravity Model of Trade}

This model has also provided an empirical explanation of international trade. This model stresses that the economic sizes and distances between nations are the primary factors that determine the patterns of trade across national boundaries. The model argued that larger economies are more likely to produce goods and services for domestic consumptions and exports than small economies. More so, these economies generate more revenues from their products sold, paving ways for people to buy more import products. The theory further stressed that the distance or geographical location between individual countries or markets has an influence on the cost of imports and exports of products. The basis of the gravity model assumes that only size and distance are the paramount drivers of trade in the following: $T_{i j}=A^{*} Y_{i}^{*} Y_{j} / D_{i j}$

Where: $T_{i j}$ is the value of trade between country $i$ and country $j, A$ is a constant term, $Y_{i}$ is the GDP of country $i, Y_{j}$ is the GDP of country $j, D_{i j}$ is the distance between two countries (country $i$ and $j$ ). This implies that, 'the value of trade between two countries is proportional, other things equal, to the product of the two nations' GDPs, and diminishes with the distance between the two countries' (Krugman, Obstfeld and Melitz, 2010, p. 12). Deardorff (1998) opined that the gravity model of trade was firstly empirically analysed by Tinbergen (1962), Pöyhönen (1963) to determine trade flows based on the gravity equation; however, they gave only intuitive justification. Pöyhönen (1963) concludes that the tentative analysis of foreign trade undoubtedly reveals the existence of structural characteristics that were bound heavily to affect the conceptions of the drivers of the geographical distribution of commerce. Arguably, the impact of trade policy could be estimated only by isolating the factors that are likely to affect the 'distribution, without ascribing the observed differences in their entirety to any single factor' (p. 7).

\subsection{New 'New Trade' Theory}

The new 'new trade theory' (NNTT) following the Ricardian, H-O model, NTT, and IIT models that emphasised that trade are mostly carried out with homogeneous products (equal in productivity). IIT stressed that trade in homogeneous products, mostly takes place in industrialized countries, while inter-industry trade with heterogeneous products takes place in both developed and developing countries. NNTT maintains that agricultural markets are often either faced with imperfect competition through the downstream or upstream sector. Farm products are modelled as differentiated and monopolistic competition along the supply chain.

The NNTT, however, has one major shortcoming: it is based on the assumption of a representative firm (Krugman, 1980), which contradicts the reality on the ground. Usually, firms are rather heterogeneous than homogeneous; i.e., firms vary in their productivities. Melitz (2003) is regarded as a pioneer that analyses the implications of firm heterogeneity for foreign trade. Melitz work also led a foundation to the NNTT. Melitz stresses that firm heterogeneity is an additional source of comparative advantage: even though on average, no firm of a particular sector might be productive enough to export, given the dispersion of its productivities. Nonetheless, there still might be some companies left, which are producing enough to export. This insight is significant as it yields an explanation for the reason nation's even exports or imports in sectors where they appear to have a comparative advantage or disadvantage. The other major impetus of Melitz model is that free trade does not only lead to resource reallocations within sectors, but also between sectors; resources are mostly reallocated from least productive companies to higher productive firms. Otherwise small firms and exporters will be forced to fold up as they could not compete favourably with the larger firms in the market, at least in the short run. Melitz (2004), nonetheless, stresses that domestic protections of infant industries would impede productivity; 
lowering protections may stimulate healthy competition and higher productivity.

As with NTT, there is now a discussion about the applicability of NNTT to agriculture. For instance, Gopinath Sheldon and Echeverria (2007) try to address this subject in a broad context. They argue in favour of NNTT. Their studies show that there might not be a direct export decision on agriculture in comparison with other industries. Notwithstanding, there may be an underlying decision in agricultural trade. Farmers are likely to be aware of the net export positions of their country on the global market and consider this information, among other things when they decide on farming more or less export-intensive commodities.

However, critics stress that the works by Gopinath Sheldon and Echeverria (2007) is rather intuitively, as hard facts are missing. The authors only intuitively motivate their position with enough empirical evidence. Nevertheless, neither farm heterogeneity in productivity nor fixed trade costs in agricultural exporting can be rejected; it conforms to the theory at least to apply agriculture trade models with firm heterogeneity. They 'are observed in multiple dimensions: productivity, size, and capital and skill intensity' (p. 17). In continuation with Melitz Model, studies of Ahn, Khandelwal and Wei (2011) confirm that firms either selects for non-export or export of agricultural products based on the volume of production. They conclude that, rather than an underlying production decision, the decisions of farmers to produce export-intensive products is directly linked to export trade.

\section{Linking Trade Theories to Food and Agriculture}

Because the climatic condition substantially determines agricultural production in the regions across the globe; scholars have recently given attention in the application of its production to trade theories. Both traditional and modern trade theories have explained why countries involve in trade and trade patterns (Verter and Bečvářová, 2014). This section briefly highlights the most referred theories of trade and made attempts to link them with agriculture, which takes lion's share of Sub-Saharan African (SSA) countries' trade.

Is the doctrine of mercantilism dead or still alive? Mercantilism model seems to have gone; however, trade in primary agriculture, is still protected which was seen as the sole features of mercantilism. For instance, export subsidies, quotas, tariffs and other forms of trade distortions by various governments worldwide, especially the advanced economies have heavily hurt Sub-Saharan Africa, which exports primary agricultural products mostly. Arguably, the doctrine of encouraging domestic production and exports and discouraging imports as postulated by mercantilism is still alive, albeit in different forms. Agricultural protectionism mostly in the West does not stand in the way of the advantages of free trade in SSA.

Even though agriculture accounts for a substantial share of the GDP 1 and labour force in SSA, none of those countries is among the top major agricultural exporters in the world (see Table 1). Instead, in some of those countries are ranked highest in agricultural imports as a percentage of their total merchandise imports (see Table 2). More so, some of the SSA countries such as Nigeria, Burundi, Central Republic of Africa, Zimbabwe, Angola, Gabon, Gambia, Niger, Rwanda and Uganda are net importers of food and agricultural products. Therefore, sadly, these agrarian countries are presently experiencing unfavourable trade balance in food and agriculture. It has become paramount to ask some questions: do not those countries have a comparative advantage or factor proportion in agriculture? If they do, then why are they not among the major exporters despite having a substantial share of their labour force in its production? Low agricultural productivity, insufficient agricultural technologies, and market distortions are identified as the reasons why SSA countries are not among the top major exporters of agricultural products. Data available from FAO (2015) shows that in the SSA, only Nigeria was among the top twenty agricultural producers in the world in $2013 .{ }^{2}$

Table 1: Major exporters and importers of food and agricultural products.

\begin{tabular}{|c|c|c|c|c|c|c|c|c|c|}
\hline \multicolumn{10}{|c|}{ Major Exporters ${ }^{3}$} \\
\hline \multirow{3}{*}{ Rank } & \multirow{2}{*}{ Word/country } & \multicolumn{4}{|c|}{ Exports (billion US\$) } & \multicolumn{4}{|c|}{$\%$ of world total } \\
\hline & & 1995 & 2005 & 2010 & 2013 & 1995 & 2005 & 2010 & 2013 \\
\hline & World & 361.0 & 538.9 & 872.1 & $1,133.0$ & 100.0 & 100.0 & 100.0 & 100.0 \\
\hline
\end{tabular}

\footnotetext{
${ }^{1}$ Agriculture, value added (\% of GDP) in 2014: Sierra Leon 62\%, Central African Republic 58\%, Chad 53\%, Ethiopia 42\%, GuineaBissau 44\%, Togo 42\%, and Burundi 39\% (World Bank, 2015).

2 Major producers: Value of gross Agricultural Production (Constant 2004-2006 Billion US\$) ranked in 2013: China (\$612), USA (\$196), India (\$191), Brazil (\$91), Turkey (\$62), Japan (\$62), and Nigeria (\$60) (FAO, 2015).

${ }^{3}$ Top ten major net exporters of agricultural products in 2013: Argentina (1), Brazil (2), Netherlands (3), India (4), Thailand (5), China (6), Australia (7), New Zealand (8), USA (9), and Vietnam (10) (UNCTAD, 2015).
} 


\begin{tabular}{|c|c|c|c|c|c|c|c|c|c|}
\hline 1 & United States & 42.2 & 48.3 & 82.7 & 107.0 & 11.7 & 9.0 & 9.5 & 9.4 \\
\hline 2 & Netherlands & 34.1 & 42.7 & 64.8 & 74.0 & 9.5 & 7.9 & 7.4 & 6.5 \\
\hline 3 & Germany & 21.2 & 35.2 & 53.0 & 68.0 & 5.9 & 6.5 & 6.1 & 6.0 \\
\hline 4 & Brazil & 10.0 & 21.8 & 45.2 & 54.0 & 2.8 & 4.0 & 5.2 & 4.8 \\
\hline 5 & China & 10.0 & 22.5 & 41.1 & 60.6 & 2.8 & 4.2 & 4.7 & 5.3 \\
\hline 6 & France & 30.3 & 32.9 & 43.8 & 53.2 & 8.4 & 6.1 & 5.0 & 4.7 \\
\hline 7 & Belgium & 11.5 & 23.6 & 31.3 & 39.4 & 3.2 & 4.4 & 3.6 & 3.5 \\
\hline 8 & Spain & 11.5 & 21.8 & 29.9 & 37.9 & 3.2 & 4.0 & 3.4 & 3.3 \\
\hline 9 & Canada & 11.7 & 20.7 & 28.5 & 36.0 & 3.2 & 3.8 & 3.3 & 3.2 \\
\hline 10 & Argentina & 7.2 & 12.4 & 22.4 & 31.8 & 2.0 & 2.3 & 2.6 & 2.8 \\
\hline \multicolumn{10}{|c|}{ Major Importers } \\
\hline \multirow{2}{*}{ Rank } & \multirow{2}{*}{ Country } & \multicolumn{4}{|c|}{ Imports (billion US\$) } & \multicolumn{4}{|c|}{$\%$ of world total } \\
\hline & & 1995 & 2005 & 2010 & 2013 & 1995 & 2005 & 2010 & 2013 \\
\hline 1 & United States & 29.4 & 55.2 & 74.5 & 93.2 & 7.8 & 9.8 & 8.4 & 8.3 \\
\hline 2 & Germany & 38.1 & 44.4 & 60.6 & 72.4 & 10.2 & 7.9 & 6.8 & 6.4 \\
\hline 3 & Japan & 45.9 & 44.8 & 52.9 & 58.6 & 12.2 & 7.9 & 6.0 & 5.2 \\
\hline 4 & United Kingdom & 20.8 & 36.0 & 46.3 & 53.2 & 5.5 & 6.4 & 5.2 & 4.7 \\
\hline 5 & France & 24.6 & 30.5 & 42.4 & 49.9 & 6.6 & 5.4 & 4.8 & 4.4 \\
\hline 6 & Netherlands & 19.5 & 24.3 & 37.8 & 45.7 & 5.2 & 4.3 & 4.3 & 4.1 \\
\hline 7 & Italy & 19.2 & 26.1 & 34.8 & 39.6 & 5.1 & 4.6 & 3.9 & 3.5 \\
\hline 8 & China & 6.1 & 9.4 & 21.6 & 41.0 & 1.6 & 1.7 & 2.4 & 3.6 \\
\hline 9 & Russia & 10.3 & 16.1 & 29.9 & 36.8 & 2.7 & 2.9 & 3.4 & 3.3 \\
\hline 10 & Belgium & 9.3 & 19.7 & 25.3 & 33.2 & 2.5 & 3.5 & 2.9 & 3.0 \\
\hline
\end{tabular}

Source: Author's computation based on World Bank, 2015, UNCTAD, 2015

Undoubtedly, without empirical observation (intuitively), the share of the labour force in agriculture available cannot adequately explain the variation of agricultural productivity, ${ }^{4}$ but capital or technology. Nonetheless, given that the top major producers are also the largest populous countries in the world, their active labour force in agriculture (i.e. China, India, Indonesia, Nigeria, and Turkey) and technology (i.e. USA, Japan, France) may account for the variations of their agricultural productivity. However, the largest exporters of agricultural producers have the lowest share of the labour force in the sector. ${ }^{5}$ On the hand, most SSA countries which agriculture is the mainstay of the economy and accounts for a substantial share of total employment ${ }^{6}$ are the lowest producers and exporters of agricultural products in world.

Classical theories of international trade emphasised that countries should produce and export what they have costs or factor advantage over another country. However, the reverse seems to be the case for agriculture as the West (i.e. USA and EU) spends huge amount of money to support producers without which most of them would not have been still in the agricultural markets. For instance, Common Agricultural Policy (CAPs) of the EU takes the highest on the Union's annual budget (in 2014, about $€ 58$ billion or 40\% of the EU's budget was for CAPs).

As postulated by Smith, Ricardo, and H-O models, some SSA countries such as Ghana, Ethiopia, Uganda, Ivory Coast and Nigeria have taken advantage of their unique and favourable tropical climatic conditions by producing and exporting agricultural commodities (i.e. absolute or comparative advantage) that could not be produced in advanced countries in large quantities despite their technical know-how. As compared to other raw agricultural products, data available indicate there is trade liberalization in some tropical agricultural products such as cocoa beans, coffee, tea, rubber and bananas. For instance, Nigeria and Ghana recorded over $55 \%$ and $75 \%$, respectively, average annual cocoa export as a percentage of domestic output between the period 1987 and 2011 (Verter and Bečvárová, 2014). Similarly, SSA accounted as top major exporters of some other tropical products, albeit in small quantities and low prices.

In the same way, statistical data available from FAO shows that in 2011: Côte d'Ivoire was the fifth exporter of rubber Nat dry; Egypt was the fourth exporter of maize; Ethiopia, Nigeria and Sudan were the 2nd, 3rd and 4th largest

${ }^{4}$ Available data from the World Bank (2015) shows countries with agriculture value added per worker (constant 2005 US\$) in 2014: Germany $\$ 39,490$, France $\$ 84,574$, Netherlands $\$ 70,859$, Belgium $\$ 68,736$, Nigeria $\$ 4,760$, Zimbabwe $\$ 279$, Uganda $\$ 215$, Sierra Leon $\$ 927$, Mozambique \$283, etc.

${ }^{5}$ Employment in agriculture (\% of total employment) and year: USA 2\% (2010), Netherlands 3\% (2011) and Germany 2\% (2012), EU 7\% (2014), Belgium 1\% (2012), Spain 4\% (2012), among others (World Bank, 2015).

${ }^{6}$ Employment in agriculture (\% of total employment) and year: Zambia 72\% (2005), Uganda 66\% (2009), Liberia 50\% (2010), Ethiopia 82 (2004), Mali 42 (2004), Sierra Leon 69\% (2004), and others (World Bank, 2015). 
exporters of Sesame seed; Côte d'Ivoire, Guinea-Bissau, Ghana and Benin were the top major exporters of cashew nuts in the world. Most of these products were exported unprocessed or partially processed. Apart from tropical agricultural commodities, traditional theories of trade appear not to stand in the case of primary agricultural products as advanced economies still restrict trade in non-tropical products.

Table 2: Food imports (\% of merchandise imports) ${ }^{7}$ by ranking.

\begin{tabular}{|l|c|c|c|c|c|c|c|c|c|c|}
\hline Country & $\mathbf{2 0 1 3}$ & $\mathbf{2 0 1 2}$ & $\mathbf{2 0 1 1}$ & $\mathbf{2 0 1 0}$ & $\mathbf{2 0 0 9}$ & $\mathbf{2 0 0 8}$ & $\mathbf{2 0 0 5}$ & $\mathbf{2 0 0 0}$ & $\mathbf{1 9 9 0}$ & $\mathbf{1 9 7 0}$ \\
\hline Benin & 40.3 & 37.9 & 33.9 & 38.6 & 31.1 & 36.1 & 29.9 & 21.9 & $\mathrm{~N} / \mathrm{A}$ & 17.8 \\
\hline The Gambia & 37.3 & 33.2 & 32.8 & 36.1 & 34.3 & 29.8 & 37.7 & 34.5 & $\mathrm{~N} / \mathrm{A}$ & 31.7 \\
\hline Kiribati & 36.2 & 33.7 & 45.1 & 40.7 & 42.3 & 40.5 & 36.4 & $\mathrm{~N} / \mathrm{A}$ & 31.4 & $\mathrm{~N} / \mathrm{A}$ \\
\hline Central African Republic & 36.0 & 29.6 & 31.2 & 28.1 & 39.3 & 25.9 & 17.2 & 29.3 & $\mathrm{~N} / \mathrm{A}$ & 16.9 \\
\hline Antigua and Barbuda & 35.6 & 37.3 & 23.9 & 21.3 & 17.6 & $\mathrm{~N} / \mathrm{A}$ & 17.6 & 21.7 & $\mathrm{~N} / \mathrm{A}$ & $\mathrm{N} / \mathrm{A}$ \\
\hline Niger & 32.9 & 31.7 & 15.8 & 15.1 & 15.5 & 24.9 & 34.2 & 38.5 & $\mathrm{~N} / \mathrm{A}$ & 14.2 \\
\hline Cabo Verde & 32.1 & 27.9 & 25.4 & 27.7 & 29.4 & 27.7 & 30.5 & 31.0 & $\mathrm{~N} / \mathrm{A}$ & $\mathrm{N} / \mathrm{A}$ \\
\hline Sao Tome and Principe & 30.6 & 30.4 & 32.4 & 29.8 & 35.9 & 27.3 & 38.4 & 30.8 & $\mathrm{~N} / \mathrm{A}$ & $\mathrm{N} / \mathrm{A}$ \\
\hline Tonga & 29.7 & 29.0 & 29.8 & 29.1 & 33.7 & 28.6 & 20.5 & 23.2 & 27.8 & $\mathrm{~N} / \mathrm{A}$ \\
\hline Yemen Rep. & 28.7 & 32.5 & 31.5 & 30.8 & 27.8 & 24.8 & 28.1 & 35.6 & $\mathrm{~N} / \mathrm{A}$ & $\mathrm{N} / \mathrm{A}$ \\
\hline Samoa & 27.3 & 25.7 & 26.1 & 24.5 & 30.1 & 25.5 & 21.3 & $\mathrm{~N} / \mathrm{A}$ & 27.1 & 29.0 \\
\hline Senegal & 23.8 & 24.1 & 23.0 & 22.4 & 24.2 & 25.9 & 28.1 & 23.3 & 28.7 & 28.9 \\
\hline
\end{tabular}

Source: Author's computation based on World Bank, 2015

Krugman (1984) provides the first theoretical explanation of the effect agricultural exports on national development. Krugman argues that the expansion of farm exports could lead to a significant increase in the demand for the countries' outputs, which in turn result in a rise in real might output. The study of IIT in food and agricultural products may the seen as a ways of determining the significance of economies of scale in agricultural trade. Early studies found that agriculture was largely an inter-industry nature, albeit raw products. However, McCorriston and Sheldon (1991) find that trade in processed food and agricultural products between the USA and the EU was largely an IIT nature.

Given that modern trade theories stress that gains from trade are heavily determined by imperfect competition, economies of scale and technological advancement, most poor producers from SSA countries are being left in the cold. As earlier mentioned, low productivity, insufficient technologies, and market distortions have been impeded SSA farmers from benefiting from a comparative advantage in agricultural products. As a consequence, they might not afford to produce in large quantities and enjoy an average cost of production. The landscape of agricultural trade is currently characterized by processed products from the West, at the expense of raw, bulk agricultural commodities substantially from the SSA countries.

\section{Conclusions}

International trade in agriculture has recently been recognized as an important driver of growth, particularly in SSA countries where agriculture is the major export products and foreign exchange earner. This paper surveys a broad range of both traditional and modern theories of trade regarding agriculture. Historically, trade in agrarian products was concentrated on comparative advantage and factor endowment models that hinged on constant returns to scale and perfect competition. The application of modern theories to agriculture has been increasing in recent years. The theories maintain that imperfect competition, product differentiation and economies of scale determine trade patterns. In this study, it could be concluded that both traditional and modern trade models help in explaining the current patterns of trade.

Even though agriculture is the primary employer of labour, principal export commodities in SSA countries, these countries are not the top major exporters of the products. Instead, some of these countries are net importers of food and agricultural products. This is partly due to limited market access, market distortions, and low productivity due to limited capital and modern technologies. For SSA countries to witness an accelerated trade balance and gain from trade, they should take advantage of their unique climatic conditions and concentrate on producing and processing in large quantities those commodities that cannot be produced by the West in large quantities for self-sufficient and exports. The WTO

${ }^{7}$ Food imports: Food comprises the commodities in SITC sections 0 (food and live animals), 1 (beverages and tobacco), and 4 (animal and vegetable oils and fats) and SITC division 22 (oil seeds, oil nuts, and oil kernels). 
should continue in pressing the advanced economies to open their markets for raw agricultural products from the SSA countries.

\section{Acknowledgements}

The author acknowledges IGA FRRMS MENDELU (No. 18/2015) for the financial assistance during the preparation of this contribution.

\section{References}

Abbott, P. C., \& Kallio, P. K. S. (1996). Implications of game theory for international agricultural trade. American Journal of Agricultural Economics, 78(3), 738-744.

Ahn, J., Khandelwal, A. K., \& Wei, S. J. (2011). The role of intermediaries in facilitating trade. Journal of International Economics, 84 (1), 73-85.

Bergstrand, J. H. (1990). The Heckscher-Ohlin-Samuelson model, the Linder hypothesis and the determinants of bilateral intra-industry trade. The Economic Journal, 100 (403), 1216-1229.

Berkum, S.V., \& Meij, H.V. (2000). The application of trade and growth theories to agriculture: A survey. The Australian Journal of Agricultural and Resource Economics, 44 (4), 505-542.

Blaug, M (1992). The methodology of economics or, how economists explain. (2nd Ed.). Cambridge: Cambridge University Press.

Bowen, H. P., Leamer, E.E., \& Sveikauskas, L. (1987). Multifactor, multicountry tests of the factor abundance theory. American Economic Review, 77 (5), 791-809.

Campi, M., Duenas, M. (2014). Intellectual property rights and international trade of agricultural products. Available at SSRN http://ssrn.com/abstract=2459830

Davis, D. R. (1995). Intra-industry trade: A Heckscher-Ohlin-Ricardo approach. Journal of International Economics, 39 (3), 201-226.

Deardorff, A. (1998). Determinants of bilateral trade: does gravity work in a neoclassical world? The regionalization of the world economy. Chicago: University of Chicago Press.

Ekelund, R. B., \& Tollison, R. D. (1981). Mercantilism as a rent-seeking society: Economic regulation in historical perspective. College Station, Tex: Texas A \& M University Press.

Erokhin, V., \& Ivolga, A. (2013). New developments in RUSSIA-EU trade with agricultural goods: Influences of trade integration. Economics of Agriculture, 60 (2), 299-308.

FAO (2015). FAOSTAT database [online]. Available at http://faostat.fao.org/ (accessed July 19, 2015).

Gopinath, M., Sheldon, I., \& Echeverria, R. (2007). Firm heterogeneity and international trade: Implications for agricultural and food industries. Trade Policy Issues Paper No 5. International Agricultural Trade Research Consortium.

Goldin, I. (1990). Comparative advantage: Theory and application to developing country agriculture (Working Paper No. 16). OECD Development Centre

Grant, R. M. (1991). Porter's competitive advantage of nations: An assessment. Strategic Management Journal, 12 (7), 535-548.

Grubel, H. G., \& Lloyd, P. (1971). The empirical measurement of intra-industry trade. Economic Record, 47(4), 494 - 517.

Heckscher, E. (1919). The effect of foreign trade on the distribution of income. Ekonomisk Tidskrift, 21, 497- 512.

Helpman, E., \& Krugman, P. R. (1986). Market structure and foreign trade: increasing returns, imperfect competition, and the international economy. Journal of Economic Literature, 24 (2), 713-715.

Helpman, E. (1999). The structure of foreign trade. Journal of Economic Perspectives, 13 (2), 121-144.

Josling el al. (2010). Understanding international trade in agricultural products, one hundred years of contributions by agricultural economists. American Journal of Agricultural Economics, 92 (2), 424-446.

Krugman, P. R. (1979). Increasing returns, monopolistic competition and international trade. Journal of International Economics, 9, 469479.

Krugman. K. (1980). Scale economies, product differentiation, and the pattern of trade. The American Economic Review, 70 (5), 950959.

Krugman, P. R. (1981). Intra-industry specialization and the gains from trade. Journal of Political Economy, 89, 959-973.

Krugman, P. R., Obstfeld, M., \& Melitz, M. J. (2010). International economics: Theory and policy. (9th Ed.) Pearson Addison-Wesley.

Leamer, E. (1980). The Leontief paradox reconsidered. Journal of Political Economy, 88 (3), 495-503.

Linder, S. B. (196I). An Essay on Trade and Transformation. New York: John Wiley

Loertscher, R., \& Wolter, F. (1980). Determinants of intra-industry trade: Among countries and across industries. Weltwirtschaftliches Archiv, 116 (2), 280-293.

Leontief, W. (1953). Domestic production and foreign trade: The American capital position re-examined. Proceedings of the American Philosophical Society, 97(4), 332-49.

McCorriston, S., \& Sheldon, I. M. (1991). Intra-industry trade and specialization in processed agricultural products: The case of the US and the EC. Review of Agricultural Economics, 13 (2), 173-184.

Melitz, M. J. (2003). The impact of trade on intra-industry reallocations and aggregate industry productivity. Econometrica, 71(6), 16951725. 
MUN, T. (1664). England's treasure by foreign trade. New York: Macmillan and Co.

Ohlin, B. (1933). Interregional and international trade. Political Science Quarterly, 49(1), 126-128.

Paul. J. (2008). International business. (4th ed.). Prentice-Hall of India Pvt. Ltd.

Pokrivčák, J., Ciaian, P., \& Kancs, A. (2011). Modelling the factor content of agricultural trade. Agricultural Economics- Czech, 57(8), 370-383.

Porter, M. E. (1990). The competitive advantage of nations. New York: Free Press.

Pöyhönen, P. (1963). A tentative model for the volume of trade between countries. Weltwirtschaftliches Archiv, 90 (1), $93-100$.

Ricardo, D. (1817). On the principles of political economy and taxation. Variorum Edition, in P. Sraffa (Ed.), Works \& Correspondence of David Ricardo, Vol. I. Cambridge: Cambridge University Press. Retrieved from Retrieved from http://bit.ly/19sFj7G (April 22, 2014)

Smith, A. (1776). An inquiry into the nature and causes of the wealth of nations. In R. H. Campbell \& A. S. Skinner (Ed.). Oxford: Oxford University Press.

Stiglitz, J. E., \& Charlton, E. (2007). Fair trade for all: How trade can promote development (Revised ed.). Oxford: Oxford University Press.

Tinbergen, J. (1962). Shaping the World Economy: Suggestions for an International Economic Policy. Books (Jan Tinbergen). Twentieth Century Fund, New York. Retrieved from http://bit.ly/1K40rxa (July 24, 2015)

Trefler, D. (1993). International factor price differences: Leontief was right! Journal of Political Economy, 101, 961-87.

United Nations Conference on Trade and Development (UNCTAD) (2015). World statistical database [Online]. Available at http://bit.ly/1CK9hmK [Accessed: July 17, 2015].

Vanek, J. (1968). The factor proportions theory: the N-factor case. Kyklos, 21 (4), 749-756.

Vernon, R. (1966). International investment and international trade in the product life cycle. Quarterly Journal of Economics, 80, 2, 190207.

Verter, V., \& Bečvářová, V. (2014). Analysis of some drivers of cocoa export in Nigeria in the era of trade liberalization. Agris on-line Papers in Economics and Informatics, 6 (4), 208-218.

Verter, N., \& Osakwe, C. N. (2015). Economic globalization and economic performance dynamics: Some new empirical evidence from Nigeria. Mediterranean Journal of Social Sciences, 6 (1), 87-96.

World Bank (2015). World development indicators 2015. World Bank, Washington, DC; ISBN 978-1-4648-0440-3. 